\title{
Imprints of the Entrepreneurial State and Privatization on Worker Subjectivity - A Study of Iron Ore Mine Workers in Itabira - Minas Gerais, Brazil
}

\author{
Maria Cecilia Minayo \\ Fundação Oswaldo Cruz, \\ Brazil
}

\section{Introduction}

This paper presents a study on changes in subjectivity of a segment of workers in the iron ore mining and processing industry in Minas Gerais, Brazil, based on their situation as employees of a state-run company that was subsequently privatized. It is not an entire coincidence that these workers went from a mode of production that was of the Fordist type to an organization of labor along the lines of the Toyotist or post-Fordist model. Therefore the entire reflection is permeated by these two diametric opposites: state-run company versus private company; Fordist organization of labor versus the Toyotist or post-Fordist model.

The concept of subjectivity employed herein includes discussions on culture. In the case of workers, according to Verret et Creusen (1996, p.120) culture is formed as "a system of works to which a specific cultural practice may give way, a system of attitudes implied by this practice, and moreover, models of behavior that regulate these attitudes under threat of social approval or disapproval and categories of thought and action produced by these models." Here I use the concept of subjectivity in the same sense attributed by Sennet (1998) and Geertz (1973), understood as part of cultural and historical conscience; and along the lines of Ortner (2007) who defines it as a set of modes of perception, affections, thoughts, desires and feelings that affect the subjects acting within specific social and cultural formations. According to the author, these formations organize and provoke said modes of thought, feeling and action, making the subjects conform to a particular identity. Thus, interpretation of the concept of subjectivity swings between giving emphasis to structures that model individuals (Durkheim, 1980; Lévy-Strauss, 1958), empowering subjects and their actions in constructing reality (Weber, 1969; Berger \& Luckamn, 1978) and highlighting the interwoven relations between the role of individuals in creating habitus (Bourdieu, 1980), which ranges from embarrassing them to identifying them in specific groups in correlation to broader society. During this study, I found both the marks of the origin and history that structured the identity and specificity of this worker group and remained pari passu with the social formation of the Brazilian worker class and history of the country and provide a counterpoint to the transformations occurring to their subjectivity, due to profound changes in the model of organization of labor. 
The study is based on the outlook of workers who for 70 years have constructed and been molded by the company Companhia Vale do Rio Doce - now officially renamed simply "Vale" - despite being contextualized in the institutional contours of the company. Due to space constraints, I will base my reflection here on a few representations of workers, regarding the two defining moments in their history: the period from 1942 to 1997 when they were employed by the state-run company, and the period from 1997 to the present when they were employed by the same post-privatization company. The concept that I use considers representations (Blin,1997) as a form of socially elaborated and shared knowledge, constituting a practical vision and contributing to construction of a common reality for a given segment or population. They are expressed through all types of language.

In the complete text (Minayo, 2008), I trace the origin, growth and transformations of this segment of Brazilian workers who, due to the significance of their production on the national and international scenario, became a prime example of the social and economic changes that took place over the past 70 years and completely revolutionized labor in the country.

This paper is organized in four parts: contextualization; methodology; analysis of social representations, and some final considerations. In particular, this reflection seeks to answer a question in the sociological and political literature regarding how workers represent their experience with a new cycle of capitalism marked by productive restructuring. Literature on the subject, both in Brazil and abroad, often without hearing workers, tends to place them as "irreversible victims of globalized capitalism," (Antunes, 1999; 2010; 2011, Alves, 200, 2009, 2010; (Sennet, 19981), which in this study is found to be overly simplistic as the reality is far more complex.

\section{Contextualization}

I make a clear distinction between the two stages that historically divide the workers' lives.

The first corresponds to the period of the state-run company (1942-1997), marked by nationalist-developmentalist ideology and corporatism (Diniz, 1978; Gomes, 1979; 1988; Cardoso, 1999; 2001), where workers were called, trained and disciplined to produce and export in the name of the interests of the nation ${ }^{2}$. In the beginning, Vale was a mixed-capital

\footnotetext{
${ }^{1}$ In The Corrosion of Character: Personal Consequences of Work in the New Capitalism, Sennett argues that working conditions have changed radically in contemporary capitalism, producing profound effects in conscience and, according to him, in character. His book discusses several types of subjectivity produced under the banner of flexibility: people must be flexible, machines must be flexible, companies must be flexible. Sennett analyzes this model as producing different effects in class segments. For example, he highlights that people like Bill Gates or other members of the "Davos-Man" species feel free with and flower within the mentality of a flexible organization: "The capacity to leave the past behind, confidence to accept fragmentation: these are two traits of character that appear in Davos among people who truly feel at home in the new capitalism" (Sennett, 1998, p. 63). Yet the same character traits become self-destructive for those who work at the lower levels, says Sennett: this model corrodes your character, making people insecure and without expectation and older people - 50 years old, or even 40 or 30, depending on the line of work - feel rejected.

${ }_{2}$ Companhia Vale do Rio Doce was formed during the 2nd World War, for the purpose of producing iron ore to build war material for the allied countries that signed to so-called "Washington Agreement"
} 
company, whose largest shareholder was the National Treasury. The federal government at the time held $90.91 \%$ of its shares and was under the jurisdiction of the Ministry of Mines and Energy. Studying the specificity of this type of entity, Lojkine (1981) showed that capitalist exploitation in them was not based on private property of capital, but on social capital instead, namely collective capital represented by the authority of the State that managed and directed them. At the time, conflicts between capital and labor did not appear in the form of divergent interests between an isolated private capitalist or group of capitalists and salaried workers. They arose under the form of contradictions between associated producers of a 'formally socialized' company (pg.51) and the official representative of the capitalist class, namely the State.

Bethelheim (1970) observed a radical difference and opposition between so-called nationalization, such as that which took place in the former Soviet Union, and the idea of socialization. Directors, appointed by the State, by government authorities, were the individuals in nationalized Soviet companies who continued to hold and control means of production, fixed and working capital and not the workers. To this author, these companies, in the strict sense of the word, are historically state apparatuses and one of the places where social capitalist relations are configured. They reproduce these relations through a double separation: of workers in relation to means of production; and companies, one from another.

This double separation constitutes a central figure in the mode of capitalist production that opposes the private nature of property or ownership, the social nature of productive forces. State capitalism and nationalizations therefore constitute formal means of partially separating these contradictions, or rather, of displacing their effects (Betleheim,1970, p.7172).

Engels (1990), contrary to Bethelheim (1970), speaks of an inversion of capitalist relations "taken to the zenith," inasmuch as State ownership of productive forces "formally" paves the way for effective socialization of means of production. He clarifies, however, that this inversion remains formal while the State is in the hands of the dominant capitalist class, which is true in the case of state-run companies in Brazil. Engels' opinions, given at a time of great euphoria over the construction of communism in the Soviet Union, however, were

between the United States, England and Brazil, on 3 March 1942. These allied countries predicted the continuation of the world conflict and feared a scarcity of raw material for the armaments industry. Each of the partners to the agreement committed to a type of collaboration. England was to return the iron ore deposits in the state of Minas Gerais to Brazil, formerly purchased by the British Itabira Company. The Brazilian government was to create a company to be responsible for mining the deposits, to take over the Vitória-Minas Railway, whose largest shareholder at the time was the same British Itabira Company, to extend the railway to Itabira and restore it so that it could bear exclusive exportation, for three years, of 1,500,000 tons/year of iron ore to England and to the United States. The US government committed itself to provide equipment and technicians for the restoration work of the precarious railway and mechanization of the mine and to provide loans through Eximbank to cover the expenditures with new equipment. Part of the agreement stated there would be a joint directorship of the national company to be created, with Brazilians and Americans, until the promissory notes issued to Eximbank were liquidated, when the full management of the company would become national. With the end of the 2nd World War, the agreements were not honored and Companhia Vale do Rio Doce spent the first 10 years of its existence running at a loss, paying workers very poorly and without a promising outlook for the future. 
seen to be false by the real socialism that ended up creating a highly corrupt and centralized state bureaucracy, bereft of any utopian sense of class equality.

In the case of the state-run companies, the corporate State manages a social and technical division of labor, associating it to a small portion of technicians and managers, who control the concept of labor, programming of production, and act as if they were the actual owners of the capital - being representatives of the capitalist State. At the same time, it creates a majority that merely executes, whether they are direct workers, or linked to the technical management of production processes. They were responsible for obtaining the greatest value for the state directors.

In turn, at least in the case of Vale, State ideology presented the Company as also having social objectives, leading the calls to work to historically consider this idea as being to their benefit. When production decreased because domestic and foreign demand decreased, the employees always maintained a firm stance, that is, their wages decreased less or remained stable. This apparent rigidness of the staff of workers may be attributed to the specificity of the mining productive process, as the operation of equipment requires a more or less constant number of workers and technicians. Yet, Vale always considered the demands of the town and of the workers, which remain highly dependent on the company. Furthermore, different statements reveal that, despite intense internal surveillance to benefit production, when Vale was state-run, there were very few layoffs of workers, which only occurred for political reasons or to set examples, for instance in the event that physical violence occurred. Pressure from workers against layoffs of colleagues due to illness, for example, managed to repress this type of attitude over the years, always under the allegation that the company "also had a social purpose" and could not act like any other that only sought profit.

After a rudimentary form of production during the first 10 years, the company gradually organized itself into a system of production that scholars refer to as Fordist. In the industrial world, the Fordist period was so named in reference to the American businessman Henry Ford (1922), who revolutionized forms of organization of labor in the 20th century, proposing the installation of production lines and promoting mass production. The design of the model was not merely limited to implementing effective forms of production, but expanded and included the sphere of social life. Ford believed that the prosperity of capitalist society depended primarily on its capacity to include the working class as consumers of the goods it produced. This would be possible as workers learned and were encouraged to save and spend within the limits of their salaries. Believing in the profound relation between the spheres of production and reproduction, Ford's interventions affected salaries and consumption, family relations, discipline of youth, formal and technical education. The locus, however, of economic hegemony and Fordist ideology in the area of production: in his view, moral and social oversight of society was the responsibility of the businessmen: "Although businessmen do not consider themselves as leaders of social movements, they are, in reality, the ones in charge. They have more influence in society than politicians, teachers and priests" (Ford, 2005, p.106).

Given the breadth and scope of its significance, I (Minayo, 2008) have used the term Fordism with two meanings: as an adjective of a type of regime of capitalist accumulation; and to characterize a mode of organization found in mining production at Vale: first mechanized 
and later semi-automated: fragmentation, simplification of functions and subordination of the work pace to machines. In this model, workers were required to perform specific and decomposed tasks, in given amounts of time, without moving from their positions, under the surveillance of supervisors. A specific and technically and administratively differentiated group was responsible for understanding the entire process and planning of activities. This period lasted until the early 1990s, when a model considered more advanced began to be implemented, as a precursor to the privatization of the company.

The second stage, namely the privatization process, did away with the privileges of the state-run company and its workers, as shown by authors such as Almeida (1999); Pinheiro et al (1992); and Dutra (1991), within a national privatization plan (PND). During the entire decade of the 1990s, a total of 120 state-run companies had their ownership transferred to private initiative as well as a share in 15 others, in order to unburden public accounts and increase productive and management efficiency (Anuatti et al, 2005). The certainty that Vale would, after privatization, seek profit as its principal ethos is present in statements by workers, as if such an objective were not also part of the scope of the state-run company. The privatization was prepared during the first seven years of the 1990s. It began with a dramatic downsizing in the number of workers and increased outsourcing, to the point where, from the nearly 6000 workers employed in 1990, there were no more than 3500 in 1997 when the company was finally privatized. The early 1990s also coincided with an internal situation of turbulence in labor relations, as in 1989 workers staged a pivotal strike against the announced downsizing of personnel, pay reductions and increased productivity demands. This strike is well remembered by workers because it was unprecedented, as it was the first strike in 44 years and involved almost the whole employee base of the company. An unprecedented revolt of workers in the past dated back to $1945^{3}$ when the company was still being formed. The 1989 strike shook up the habitual submission of workers ${ }^{4}$, and was organized by CUT - Unified Workers Central (Central Única dos

\footnotetext{
${ }^{3}$ The strike took place in $1945^{3}$, in a period of great economic difficulty suffered by the young company, and was repressed by a strong police force from Belo Horizonte, the capital of the state of Minas Gerais. The leaders were arrested and summarily fired. This strike took place within the following context: the terms of the Washington Agreement were being only partially fulfilled, because of the context of the post-war depression, when the international ore market entered into recession. In 1944 Vale managed to export 127,194 tons of iron ore and in 1945 sales dropped to 101,694 tons/year. These amounts were ten times lower than those prescribed in the agreement (1,500,000 tons/year). In 1945, England unilaterally cancelled its purchase contract with Brazil, while the United States decreased the pace of its collaboration. Only in 1944 did this country begin to fulfill its part of the agreement that provided the sending of equipment to fit out the railway to take ore from Itabira to the port located in the state of Espírito Santo and for the mining itself, This historical period left the Brazilian government alone to bankroll building of the Company at the same time that it was running at a loss in the country and in the international market. This meant, among other burdens, to maintain the contingent of 6,000 workers needed to run the recently-formed company, which, at the time, required intensive labor, as all the work was manual. Under these circumstances, a serious crisis began regarding the company's viability, and 1945 marked the lowest point in the recession and a spate of intense spending cuts, causing, as it always does, strong pressure on workers who were outraged and staged the only strike in its 40 years of history (Pimenta, 1981).

4 The Vale Workers Union was created in 1946, by the CEO of the company, to contain rebellions and avert strikes like the one that occurred in 1945. He therefore put workers he trusted at the helm of the entity, especially employees who worked in the human resources department. Therefore, the union
} 
Trabalhadores in Portuguese) at the time considered the most progressive union organization in the country. Union leaders managed to mobilize the entire collective workforce; coordinating, convincing and concentrating solidarity of social forces in the municipality; reaching out to and attracting regional and national attention to their movement. This event, however, in the words of the Union president at the time, was "the last gasp of an era," and preceded the period of "fear and uncertainty."

The privatization process coincided with the productive restructuring. This began, however, before the change in the company's status took place, precisely as a preparatory rite. Labor flexibility intensified in the 1990s, as the period of the 1970s and 1980s, which corresponded to the crisis of Fordism in Europe and in North America (Harvey, 2001), while here an expansion of industrial capacity was taking place, due to large-scale admittance of foreign companies, seeking to expand their production and markets. Many incentives offered by the government, among them low cost of labor, favored such a situation. The 1970s were marked by rapid expansion of iron ore mining, expansion of the labor market and investment in the State-based and triumphalist ideology called "Great Brazil" ("Brazil Grande") which was a hallmark of the military governments (1964-1978) ${ }^{5}$. This period witnessed the consolidation of Vale, which had tried to make its mark in the national and international market for the previous twenty-five years of its existence. In the memories of the workers, this was the time of abundance and optimism and for Itabira a period of economic effervescence, a boom in civil construction and the real estate market, which transformed the city into a dynamic center for industrial labor and municipal tax revenue. Anxiety over changes in the management of workers, however, was already cited in strategic planning instruments prepared by Vale management since 1979, coinciding with transformations in labor organization that had been taking place in Japan, Europe and the United States (Harvey, 2001). This first period undoubtedly carried the seeds of the transformations that would later take place, that were still characterized by investments in structuring labor, increasing specialization of labor and complexity of levels of hierarchy and management of labor.

The first signs, as part of the mining expansion stage, came with the introduction of the outsourcing of processes and labor in the 1980s. This period also saw the first topical attempts to introduce new technologies of labor organization mirroring those of Toyota, such as Quality Control Circles (QCC). However, the model of production, hierarchization and discipline of the productive force continued as before.

The productive restructuring process was concluded in 1997 with privatization, and was marked by profound objective transformations based on the systematic development of a new model of productive organization. This involved the emergence of a new and tenuous labor situation and in new forms of acculturation of workers, resulting in the fragmentation

historically always functioned bureaucratically to address individual complaints and to provide some sort of social service, such as medical, dental assistance and aid to those most needy.

5 The so-called ideology of "Brazil Grande" (Great Brazil) that marked Brazil during the years of the military dictatorship (1964-1978) can be defined as a result of a set of authoritarian measures: strong intervention of the State in the economy (growth of gross domestic product (GDP) by about $10 \%$ per year), accelerated implementation of capitalism and consolidation of an urban-industrial society, with exclusion of the working classes from national political decision-making, suppression of democratic freedoms and repressive legal interventions. 
of the class. Changes in objective and material dimensions corresponded to subjective and ideological transformations that modified the formal and mental structures of the workers, within certain special characteristics: alterations in the composition of labor and significant reduction in the number of jobs; decrease of hierarchies and integration of workers in enhancement of processes and results; participation of women in the productive process that had previously been totally dominated by men; increased proportion of outsourced workers; increasingly more elaborate forms of involvement of workers with company objectives; weakening of unions and flexible workers' rights. Inspired by Toyota, the changes presented certain assumptions: transfer of responsibility for production to the workers themselves; incorporation of knowledge that workers acquired in practice to the productive process and to the company environment; and increased productivity through teamwork.

All these movements of transformation sought to enhance Vale's solidity and competitiveness, as its tentacles extended and spread further across the globe, ever expanding and diversifying. The company's brain center was transported to the central offices, where the comparative advantages of its products, interests and changes in the domestic and international economic, financial, political, cultural, technological and symbolic scenarios were planned, analyzed and assessed. The accelerated pulse of the changing Vale was ever more present in the nervousness of the São Paulo stock exchange and in success indicators witnessed in the New York stock exchange.

The company was rapidly becoming a true multinational. In areas near the part that remained in Itabira, Vale bought mining companies around the state of Minas Gerais, establishing a virtual monopoly in the production of iron ore and other minerals, as well as in specialized labor. It also expanded to the Amazon region and throughout the world. It boasts clients in over thirty countries and it currently has business offices in North America, Europe and Asia.

In the predictable yet volatile business scenario, Vale became the largest iron ore producer and exporter in the world, and the second largest producer of manganese and one of the major producers of gold. The Company currently manages the two most productive railways in the country and holds shares in four others. In addition to participating in partnerships in several port terminals, it has its own maritime shipping company.

Currently, the complexity of its business goes far beyond the mines and seems quite confusing to workers, who have come to name it, "the monster out there." Observing the tentacles of the giant system of Vale might lead one to conclude, from the standpoint of capitalist interests, that Itabira and the workers that built it have become a tiny speck on the map of the goldmine. Only a historical and relatively small part has remained in the city. No one can take from this nearly 300 -year-old city - which was born in the gold mining cycle in Brazil and especially in Minas Gerais in the 18th century - the merit of representing history, production, product, memory and being a monument to Vale.

Objective and subjective changes that occurred during the productive restructuring and privatization tend to overlap. As I was conducting this research, I came to realize that there is no single powerful provision that abruptly created an alternative scenario to the traditional forms of labor organization. There is, rather, a systemic set of keys concomitantly activated to lead to a progressive opening of new labor relations that is underway. And, 
contradictorily, the new is constructed precisely to maintain the strength of that which is more perennial and older in the logic than what it has been replaced with: the increasingly more complete and finished realization of forms of capitalist accumulation. As Araújo (2001) reminds: "the specific characteristics of the regime of Toyota regulation allow intensification of labor taken to a degree difficult to achieve in a regime where organization of workers in the workplace were independent and capable of obtaining concessions" (p.36). In its subjective sense, labor organization within the Fordist model gave priority to serialization, standardization, hierarchization and obedience to orders. The paradigm of flexibility, however, affects the whole chain of production and reproduction of life, appealing to creativity and to group work, and may be interpreted as an ideology "that reconstructs capitalist exploitation with objective and subjective implications and increasingly links material and immaterial work. In the sphere of collective intelligence and corporate cognition, it seeks new ballast for production of value" (Alves, 2002, p.90).

As a counterpoint to the changes and pressure on the pace of work and demands for productivity, transformations in behavior, mentality and practices of workers are much slower, as culture does not change with the flick of a switch. Thus, there are elements of the old that configure the new, contaminating it and targeting it for resistance, just as the new existed in the old forewarning of a time to come. This becomes evident in the deconstruction of the Fordist logic in the period of insecurity and fear - an expression that refers to the time of transition from one type of organization to another - when crises of insatisfaction with current management, technical, relation-related and ideological methods come to the fore. Two things said by supervisors speak of this dialectic movement between technique and subjectivity, making clear the contradictions these team leaders have to manage on a day-today basis:

In Itabira today you have two situations. A group of employees in the Cauê Mine with an average of 18 to 19 years on the job is the oldest plant. Then there's a shift with an average of 11, 12 years. Average age is steadily decreasing. The older the employee, the harder it is to adapt. People get a bit lost with this talk of participation, new technologies, and changes of pace. It's a lot harder.

The second, answering a question about what he appreciated least in his life at work nowadays, after praising the new forms of current productive organization several times, confessed:

What I like least is the issue of antagonism, the focus some people within the company have on others. Currently at Vale there are plenty of new faces and a lot of older people who were there under a different regime, a different period. So conflicts that these people create are intense, which is something you see 24/7. This differentiated focus between these two classes of people makes both work and relationships difficult.

These statements show the new face of permanent relations and hierarchy-related conflicts under either regime. A slip of the tongue led the supervisor to call the two antagonist sides "two classes of people," in other words, he used terms that are now rarely heard and when used indicate contradictions between workers and bosses. He appropriated them to refer to profound differences between two cultures within the same segment of workers who are in permanent and silent conflict in the labor process.

The changes I mention cannot be interpreted merely locally. From statements and stories told by the workers themselves, they exemplify the flow of global transformations in which 
restructuring of production is a part and that most scholars call globalization. To situate this concept - which is not the scope of this paper - I will only mention a few of its general characteristics, summarized in ideas of some of the most experienced scholars on the subject: (1) accelerated internationalization of companies, from the late 1970s onwards. This growth was spurred by liberalization of markets and by changes in the content of trades of manufactured goods for financial and telecommunications services (Kunar, 1995; Chesnais, 1996; Waddington, 1999; Harvey, 2001); (2) rapid deregulation and internationalization of financial markets, intensifying flows that now operate in real time, transcending distances and borders (Waddington, 1999; Araújo, 2001; Boito Jr, 1999) (3) technological revolution in the field of transport, communication and information transmission and processing, which has reduced times and distances, allowing transformation of what is produced and how it is produced (Araújo, 2001; Araújo et al, 2001; Alves, 1999; 2000; 2002; Mattoso, 1995; Castells, 1996; Castells, 1998; Ohmae, 1990).

It is also important to stress that this group of miners in Itabira is part of the constitution of the Brazilian worker class (Alveal, 1993; Carleal et al, 1997; Gomes, 1979; 1988), of historic changes that occurred in the country and its economy since the 1940s (Diniz, 1978; Tauille, 2001), of transformations in labor and unions as organizations of vested interest (Cardoso, 1999; 2001; Alves, 2002; Leite Lopes, 2009; Antunes, 2011); and of new forms of social relations of production, during a period of globalization and technological revolution (Minayo, 2008; Antunes, 1999; 2009; 2011; Alves, 2000; Araújo et al, 2001).

\section{Method}

This study is in the line of research known as "workers' anthropology," still in fashion, yet in its heyday it was espoused by renowned anthropologists and ethno-historians, such as Bourdieu (1963); Verret and Creusen (1996); Hoggart (1973); Leite Lopes (1976; 2009); Murard and Zilberma (1980); Thompson (1968); and Minayo (2008).

The group under study resides and works in the city of Itabira, a city of 100,000 inhabitants where Companhia Vale, which is now the largest iron ore mining and export company in the world, was established in 1942.

This paper was based on interviews with 104 miners at Vale and 10 other complementary interviews where I approached people in town and hierarchical authorities within the company. It also contains field observations. The interviews include workers of different ages, recently employed and old-timers, who worked at Vale when it was a state-run company, who lived through the transition and continued in their jobs as well as those who joined the Company only after it was privatized. Additionally, I interviewed some pensioners, both recent and from years ago, because of the objective importance of these workers to an understanding of the internal collective logic of the workers. Their own colleagues, who lived in the relatively small town whose economy continues to be dependent on Vale (Minayo, 2008) and the majority of whom have ties of kinship with them, consider these older employees a repository of accumulated collective wisdom, safeguarded and transmitted throughout the 70 years of the Company's existence. I also participated in technical meetings of the human resources sector to discuss issues linked to workers' culture, by special invitation of the group. The work as a whole also includes the sphere of social reproduction: a group of relatives, neighbors and town authorities. 
The work was conducted in two stages: from 1984-1986 and 2004-2006. During both periods, I heard the stories of production workers in different departments of ore mining, ore treatment and equipment maintenance. Within the interviewees there were assistants; machine operators, mechanized equipment and facilities operators; qualified and specialized workers; supervisors and managers. The vision of a small number of supervisors and managers, currently completely integrated in the productive process and not only performing activities of surveillance and control, helped me to understand their logic of action, especially at the time of production restructuring when they are trained for Total Quality Management, TQM, a fundamental control strategy of current forms of labor organization.

I preceded the empirical research with a broad theoretical study on the subjects addressed herein, emphasizing literature on underground and open pit mining; the kind of economic enterprise that an export-oriented mining company is; the specificity of a state-run company as opposed to a private company; the two predominant productive systems: Fordist and the Toyota or Post-Fordist model; the concepts of labor processes and general production conditions that helped structure the history of the workers; and scenarios from this history: Vale and Itabira. Also part of my field work was a sample-based study of the archived documents containing the records of retired, deceased, laid-off employees or those who spontaneously left Vale, as well as access to internal communication material of the company regarding regulating the lives of employees. Likewise, I conducted a survey of bibliographical material on the city at the local branch of the Brazilian Institute of Geography and Statistics (IBGE) and City Hall.

I focused the research unit on the workers' center that interacted directly in iron ore mining and concentration, and machine and equipment control and maintenance. As the company has several mining units, I decided to approach workers directly at a mine (the oldest mine that concentrates the largest number of workers) called Cauê, as it involves the most complex operations and is the most appropriate space to follow all of the steps of change in the labor process. It should be stressed that in the study on the current stage, I interviewed three women who worked in field operations, while in the first phase of the research, only men were working in productive activities. The only women hired were restricted to administrative activities. Whatever the circumstances, mining continues to be an eminently male-dominated activity and women in operations are still the exception.

In my field work, I adopted a basic procedure in communicating with those interviewed, namely the life story technique (in this case, the life story of the person as a worker), through open interviews. These interviews were conducted in an informal manner as a "chat with a purpose" seeking to make the interviewees feel free to narrate the steps in their lives as workers as they deemed relevant, defining their situation and attributing meanings. Together with these procedures, I also adopted the technique of direct observation. Naturally, I did not have the intention or objective conditions to work in the activities conducted by the workers, which actually would have been totally impractical. By direct observation involving the expression of my curiosity and many questions about the mining area, I visited several times, always accompanied by a worker sent by the company. Thus, the focus of my observation, understanding and interpretation was the experience and reports of the workers. I also adopted a field diary as a means of recording what I experienced and observed. 
Some workers were contacted and interviewed by me during their working hours, a situation facilitated by supervisors informed about the topic of the study. The majority, however, were approached outside the company, in places chosen by them: their homes, a bar, the union office or even a public square in their neighborhood. After the company was privatized, I found it more difficult to interview workers in their workplace; therefore the majority of communications took place outside this space. I taped almost all conversations, always with the consent of the interviewees. This procedure sought to maintain maximum fidelity to what the informants said, justified by the fact that the analysis of their representations is the focus of the study. There were only two refusals to record, and in this case they were not production workers, but people linked to administrative areas that preferred to provide information without being identified.

Having all the basic material for the research in hand, I faithfully transcribed all of the interviews (in the case of those not recorded, I wrote them down immediately after the interviews), organized the data collected, both transcriptions as well as observations, through empirical categories that appeared in the material. Thus, I prepared different titles that held primary information, thereby creating an organized view of the whole.

I then proceeded to classify the data, based on structures of relevance established through two procedures: incidence of emphasis in certain aspects of reality, based on an ordering of field information; and comparing empirical material with existing theories on the subjects classified. For example, based on this initial classification of field material I discovered that the best form of narrating this saga would be to focus on it from the different labor processes and general conditions of production that changed over time, as in general, the stories of the workers presented these structuring elements. Both concepts, however, are highly theoretical and abstract to make them operative, and I therefore sought to attribute them with the empirical categories cited by the workers (Minayo, 2008). I thus sought to understand the implications that changes in the labor process had on the social life and subjectivity of the workers, and observed a completely unbreakable bond between the world of production, reproduction and its symbolic universe.

The attempt to configure the mining center, making it the labor process with general conditions of production as the bias (Marx, 1978) in their dynamic and change-related aspects, led me to read and consider the statements of the workers, sometimes as witnesses of a history that they recall through their point of view, and at others, as representations to understand their worldview. In the analysis, these two forms of working with the data complement each other and overlap.

\section{Permanence and changes in subjectivity of workers at Vale}

In my opinion the socialization of labor is not limited to the development of technical skills that make workers able to perform their tasks. On a broader scale, the objective is to constitute workers as operators, which means combining a set of technical skills in their training with a set of convenient behavior patterns, ideas and attitudes, which, from the standpoint of capital, would form the ideal worker. Reinterpreted by the workers, these provisions are internalized and organize the elements of their culture.

The initiative to reflect on the worldview of miners is specifically based on two seminal authors, Max Weber (1969), one of the founders of sociology; and Harvey (2001), an 
important scholar of productive restructuring. Weber, studying the role of the protestant ethic in the implementation of capitalism observed that the entire economic attitude is informed by a system of beliefs and moreover the entire economic system, to maintain itself, requires broad concepts of the world, able to encompass different strata of a given society.

The more recent version of this theory is found in Harvey (2001), who, looking at the issue of the Toyota model - or as some authors prefer, post-Fordism - consider that disciplining the workforce for purposes of accumulation of capital involves a mixture of repression, familiarization, co-opting and cooperation, namely elements that must be organized not only in the workplace but also in society at large. Socialization of workers under conditions of capitalist production requires broad social control of physical and mental capacities, including education, training, persuasion, mobilization of certain social sentiments and psychological propensities.

Agreeing with the abovementioned thinkers, I sought to analyze how the broad conceptions were synthesized in the social representations of Vale workers in Itabira. Likewise, I delve deeper into what this social group specifically offers in its manner of viewing the world and life. It certainly becomes far more difficult to determine what is peculiar to miners at Vale in relation to other categories of workers, as it is the condition of the industrial worker in the capitalist mode of production (salaries, hierarchic control, cooperation in production, among other elements) that provide a common base to the categories of thought, action and symbolic expression of the working class. Specificity, when it exists, is found in the specific conditions of their production and reproduction.

The elements used herein for analysis are categories of thought and action taken from the set of interviews, enabling a discussion on their concept of labor, time and space, and society.

\subsection{Representations on work}

In industrial society, work is a particular virtue that the capitalist wishes to find in workers and for which he chooses and educates (Weber, 1967). In the so-called post-modern, postindustrial or knowledge and information society, work is a category looked at by many theoreticians and considered almost as a privilege to workers. Unlike the artisan whose objective is the product or the peasant whose concept of activity is linked to a social ethic (there is always something to do and idleness is a moral fault), the collective industrial workers' objective is the product in which they individually feel pride.

To Vale miners in Itabira, work, before all else, has the meaning of a "job." As employment, work presents itself as an economic function linked to a sentiment of institutional belonging. As a salaried-job, it is conceived as an existential need for survival and reproduction. As a jobat-Vale, in addition to the meaning of duty, it assumes connotations of a privilege achieved (Blauner, 1964).

The job, according to what most of the older workers said, enabled them to support their families (in almost all life stories there is mention of getting a job as a condition to be able to marry and have children); and "job at Vale" always provided them, in addition to respectability, dignity, status and prestige among workers from other companies. Comparing them to those "outside the Company," two elements distinguished the elder from current employees. For the former, the job gave them a salary much higher than the average 
regional remuneration and a strong sense of security: to be at Vale was guaranteed job security, from admission to retirement, a situation affected only in cases of severe breach of discipline. For current miners, in the context of the profound changes in the organizational process of the company and facing a far more restrictive labor market, the job at the Company continues to be seen as a privilege. The idea of security, however, has changed directions, becoming less centered on guarantees offered by the company and much more focused on the individual capacity and performance of the workers.

Yesterday and today, in addition to the economic function, work to miners has a connotation of providing order to life. First and foremost, it promotes interior growth and is a source of recognition, both within the family and family groups, neighbors, friends and fellow citizens. Differences in relation to the past are due to the fact that, in relation to broader society, the older workers conceived of their work as the very practice of citizenship, considering it as their best contribution to society. Current workers, expand, in concept and in practice, the vision of social and political participation, before restricted to mining activities, becoming more critical, more active and therefore more active in local society and national debates. All, however, recent and older, work constitutes an allengulfing concept of the meaning of life, due to objective production conditions, at accelerated pace in shifts that interfere with domestic and social routines. Around it they organize their schedules, social life, leisure, professional training, with little time left for other existential dimensions.

To understand the power that the representation of work has to workers at Vale, there is nothing better than understanding the feelings of insecurity and fear of being laid off, which is heightened right now among them. The awareness of excess labor at the moment, result of changes made by productive restructuring, (most households have one or more family members unemployed: sons, brothers or some working-age relative), heightens what is called specific feeling of insecurity of worker psychology, which translates the true essence of what it is to be a salaried worker. In almost all of the narratives I heard, this fear shows itself in a variety of forms, involving the physical and emotional energies of the miners.

Lay-offs in large numbers that occurred for disciplinary reasons or because activities in certain sectors were outsourced from the 1990s onwards, created an environment of lack of emotional compensation for those who were victims of the cuts. In the same vein, studying the living conditions of workers in Algeria, Bourdieu (1963, p.257) observed that the "conscience of unemployment" is the result of a capitalist advance, and that it occurs specifically among workers of large industries, as opposed to the situation of security and order in life that stable work produces. In the case of the laid-off miners, many broke up with their families, lost their references, fell into depression or even attempted suicide or actually did so, thus suffering the disruptive effects of unemployment on the totality of their lives.

Thus, we may conclude that for miners at Vale, being employed, both yesterday and today, has become synonymous with dignity and social integration, while unemployment destroys not only the basis of economic support of the family, but the entire consensus of approval of the social universe that surrounds them. Fear and insecurity of workers in the past and in the present keeps them pragmatic and demobilized, subservient to company demands, silent when faced with adverse and oppressive working conditions, so that many become complacent, in an attitude of convenience: "It's really bad, the salary is really low, but the only 
good place is in Heaven. For us it's alright, when we look around at what's happening outside, everybody jobless, people starving, the only good place is Heaven above!" said one facility operator, reflecting the sentiments of the majority.

In turn, the existence of unemployment inside families and the conscience of insecurity, nowadays a conditioning factor in labor relations, has promoted strong solidarity, the dimension of which is striking in the group observed. Some workers support three, four, five children of working age, even married children, because they are unemployed. This dimension of mutual protection, however, does not indicate complacency with the situation among those out of work. Generally, there is strong family and group mobilization, seeking to help resolve the problems of disadvantaged members. Since Vale workers disapprove morally of those they deem "lazy," "witless," or "mischievous." unemployment is seen as shameful and almost as social mutilation.

There is a peculiar trait in the concept of work among current miners, in the manner in which they address the future of their children. This aspect is quite acute in the specific situation of the large surplus of labor and the trend to shut down the mine progressively as it has been mined with increased intensity, precisely because the machines with which they currently work allow them huge gains of scale in their mining. Thus, if, on the one hand, there is the undeniable effort of post-privatization workers to ensure that family reproduction (education, health, food) occurs under better conditions than theirs did, on the other, there is a more open attitude of letting each young person bear the concern of building his or her own future. In other words, they do not see a line of continuity in the local mining market, as was true 20 years ago, when families would settle down, because their children had almost guaranteed employment.

Therefore, to current workers, work at Vale is a guarantee of the present and increasingly less security for the future. Therefore, there is no longer the concern to ensure, for themselves or for their family, the legacy of inherited employment. Generally, strategies of workers at the privatized Vale are guided by living the present intensely and ensuring employability, through competence, wherever and whenever possible. Reference is made in the statements to forecast exhaustion of the mines in Itabira, and I observed a realist stance of people who have internalized the condition of salaried laborer without the sensation of existential loss, as occurs with those laid-off during the period of Mother Vale or from the transition period. Miners demonstrate a serene pragmatism, as if to say their town is their work place. Therefore, if possibilities run out here, other perspectives will appear further ahead, with the condition that one must dedicate oneself to personal enhancement of skills, competence and professional behavior. Actually, this opening up of horizons and possibilities has been occurring in practice, inasmuch as placement exams are national and sometimes international, and some workers originally from Itabira are today in hundreds of the company's other units around the country and abroad in various levels: as simple workers, technicians, engineers and even management. Everyone knows, however, that this town and this vibrant center of worker competence and culture gave birth to the colossal Company that today has 80,000 direct employees, fulfilling its mission.

\subsection{Representations of space and time}

Nothing has warranted so much effort of capital in the socialization of workers, as the rational organization of time and space, since, in the corporate calculation, "time is money" 
and the logic of profit is based on it. Since its inception, Vale started to impress on the lives of the miners a daily routine to which not only was the physical body subject, but upon which the meaning of life was based. Any threat to this order, considered almost as second nature, causes a sensation of chaos and incoherence among the workers themselves.

In terms of space, the workers' daily life is demarcated by a triangular circuit: work-homeneighborhood. This universe, particularly in the initial phases of the workers' history, took on the dimension of the world, reinforcing, on one hand, relations of loyalty with the neighborhood, and on the other, the dichotomy between the company and larger civil society. There was the intention on the part of the company from the very beginning of the training of the workers to reinforce the political-moral investment in the mentality that organizes life centered on the mine's activities. Everything was pointed towards this: family routine, "your home is only complete when you return," (a company slogan placed on the exit gate of the mine to this day, even after privatization), the role of women as wives who take care of the home to receive the husband and care for his measured and controlled rest and recreation. Thus, the general conditions of reproduction submit to the objective of causing a sort of instrumental equilibrium, so that the space outside the work unit safeguards the cycle of maintenance and recovery of energies to be expended the following day in the productive process. Authors such as Weber (1967) and later Gramsci (1978) in their studies have written much about how Puritan ideologies have become supports to capitalist progress, by controlling the sphere of the family and even sexual life. If, at the onset of capitalism, Protestantism played a fundamental role in this orientation, these ideas spread throughout the labor world, touched on by forms of organization of production and by the logic of profit.

The ordering of time and space (work time-free time, mine-home) appears quite crystallized in the mentality of workers, both older ones and those who joined the Company after production restructuring. Nowadays, however, at least one other element is inserted into this routine, especially among young people who use their rest periods to raise or enhance their formal education, due to demands of the competitive job market and due to job insecurity, which expands their space for relations.

This repetitive and restricted organization of time and space has been showing its perverse side, through those who, due to retirement, had to abandon the routine through which they socialized. Beginning in the 1970s, retirement became a routine fact in the social life of workers, a process that gained momentum with production restructuring, through voluntary lay-off plans used since the early 1990s for the purpose of lowering payrolls and other costs. Many of the men removed from their daily mining routines later experienced a sort of incoherence in the dimensions of time and space, as if some internal disorder had affected them. Work as the ordering element lost pride of place and home and neighborhood were no longer enough to provide meaning to their lives. With few exceptions - which were with workers who had a higher degree of education or were more professionally versatile - which does not invalidate the analysis of the collective, the retired miners, conditioned to the routine of time and space delimited by the company, tended to lose their frame of reference and their group of fellowship. Conflicts and tensions caused by them in their families are common and several have had premature deaths, as they had lost the very reason for their existence, which had previously been fulfilled by their working life. 
Obviously, many premature deaths of retirees are caused by excessive physical wear and pollution from the mining process. This is especially true of older workers where muscular strength was absolutely necessary to perform their production tasks. Many of these premature deaths, however, may be associated, according to statements made by workers, to poor cultural and emotional adjustment. "Either the guy stays there trying his wife's patience or he goes down to the bar and gets drunk," said one of the interviewees, analyzing the large number of men who currently frequent bars. Actually, as an individual educated and socialized to produce and reproduce in function of an absorbing activity, the retired miner generally is unable, by himself, to discover another social motivation that fulfills him in life. Once work has configured itself as the global meaning of existence, when the scenario changes, chaos is unleashed within the worker's personality and social life. The "honest, serious, sober worker" according to one of the interviewees, often gives way to the "sedentary, alcoholic retiree (who before drank socially, so as not to compromise his work), and sometimes no longer deserves the respect of family and neighbors."

This reality has been a concern to the medical and social departments of the company since privatization, and today they encourage employees to cultivate other habits in life. Many report that bosses tell them they should rest, go out, take vacations and that work cannot and should not be the only objective in their lives. Some even report that it is currently considered as negative in the company for workers to be obsessed with their jobs. "Today it invests in quality of life, insists that we have recreation, and doesn't like compulsive workers, which is negative." In practice, however, the same regime that currently includes among its premises concern with the quality of life of workers, promotes non-stop shifts, incentives for workers to study and take technical courses when off work, and demands readiness - now measured by mobile phones workers are required to carry - to answer calls in case of absence of colleagues, problems with machinery or with other devices that cannot shut down. In other words, the central place of work is complete and continuous, as it completely occupies the real and symbolic space of reproduction, demanding physical and mental dedication of its employees.

Among these workers, however, there is another meaning to the concepts of time and space. There is a relational conception that opposes the industrial form of marking shifts and production timetables in hours, days, months and years. This differentiated mode of dating occurrences in time, Evans Pritchard $(1978,122)$ called "structural time." Telling their stories, workers tend to relate their saga and events that they took part in, not by chronological order, but by the relevance that certain facts had on their lives and on the collective lives, linking them to successive management teams at Vale. In the case of the older miners, the emphasis is on two very specific time periods: the beginning and currently. Past experiences are framed in a special way in the present and it is in retrospect that stories are told. The relational perspective of narratives indicates that, beyond any technical dimension, they experience the labor process by integrating several dimensions of social and emotional life: their socioeconomic, political and ideological aspects. The sense of coalescence that joins and articulates the past and present has, for the miners, an importance function of expressing their presence, as stakeholders in the historic transformation that has taken place in the city and in the Company. Employees of the privatized Vale, emphasize relational time in the present: particularly in the interaction with their groups of work colleagues that increasingly act as small collectives. Many, however, question the lack of differentiation promoted 
through teamwork. Many increasingly expand their concept of interactions to outside the company, investing in other environments, such as colleagues in courses, members of the same religious persuasion, community associations or among colleagues who have risen in the company or left for elsewhere.

The concept of structural space, also developed by Evans Pritchard (1978, p.123) to refer to the social distance between groups of people within a given system and that is expressed in values, was also quite useful for this analysis. The form of seeing territory is informed by experience that places the events experienced in more or less important positions according to their value in the person's personal history. Workers make constant references to "here inside" and "there outside" and are the spatial synonyms to the relational pair "us" and "others." "Here inside" is Vale with everything it means to workers in their daily lives and dreams: relations of production, salary, reproduction and expectations, both for the older as well as newer employees. "Here inside" is the known, protected, more or less safe world of the company and that, in other times, when it was state-run, was the haven they called "Mother-Vale." Even though in reality this goes far beyond the workers' experience, to them, the Company always was the space of integration, even more so in the past. In the present as well, the ideology of the "victorious, dynamic company, the largest in the world" feeds, gives meaning and consistency to the corporate cultural imagery. "Here inside," therefore, is the imaginary line drawn between miners and other workers, Vale and other companies, the city and other cities.

The workers have created a curious geography: their imagery goes from "Company" to "Brazil" and to the "world." "Brazil" and "world" are generic and abstract categories that to them mean the expanded space of relevance of their contribution. The ore "goes out to the world and returns to Brazil as revenue." This "world comes with dollars to pay the country's debt and to make it rich and that's why we have to produce and we cannot stop." These were typical phrases, repeated by older miners and that are now repeated with certain nuances. The incommensurable space of Brazil and the world provided the older workers with the dimension of work as "civic duty" - a duty that they fulfilled - but that, for most, was limited to the production unit. Allowing themselves to be exploited was confused with contributing to the greatness of the country, since to them, the state-run company also summed up the meaning of nation. Currently, such phrases are complemented by other terms, such as "make profit," "competitiveness," "shares" and "productivity balances," stripping their collaboration with the company of its social and political meaning.

Summarizing, the expression "here inside" that permeates the narratives of the tales of the older and younger workers, in the case of the former, feeds in them the idea that Vale existed as a self-sufficient micro-society and that it was capable of fulfilling the economic, social, political and cultural meaning of their lives. Presently, the expression still denotes a very well-constructed 'esprit de corps,' although linked to innumerable tentacles and networks that have made the company much more complex and dynamic. The term "there outside" does not only refer to the ecological dimension. It may designate the city, other industries and anything beyond the bounds of Vale. In the conscience of the older miners, this binary division of space was structured by actions of the Company that pitted them against citizens, privatizing their neighborhoods, absorbing them into the world of labor and depriving them of the organic solidarity of broader society. This concept of noncitizenship that for a long period informed the conscience of the workers became 
responsible for a sort of miner mentality that desolated them for a long time. Workers from the period of productive restructuring, already part of the space of the city in all its scope, present other categories of reference to address space, incorporating political entities, social concerns and solidarity into their vocabulary. The "there outside," category continues to inform the worldview of those who joined Vale after privatization, no longer has such a radical meaning of structuring their lives. It also refers to other spaces that the workercitizen should increasingly approach: the city that needs help in its construction; that of less privileged classmates in whom one should take interest, making them part of the union or in concerns regarding solidarity; that of the broader labor market, for which one must be open, prepared, alert and available.

\subsection{Representations of society}

Similarly to the division of relational space being processed in terms of "here inside" and "there outside," society is conceived, by miners, as if it were divided into "us" and "them," with strong ties between this type of concept and the previously discussed dimensions. While the representation of space in institutional and corporate life, " $u s^{\prime \prime}$ and "them" reveals a vision of class in the social structure. "Us," refers to themselves and to workers in general: "the pawns," "migrants," the "poor," "workers at Vale." "Them" are the bosses, chiefs, those in charge, supervisors and managers. "Them," also refers to the set of institutions that wield dominant power and ideology and are beyond the control and understanding of their daily affairs and limited social lives.

This division was far more clear-cut among workers who experienced the split between the public city and private city, a situation that lasted until the 1980s, when there were neighborhoods built by the company and that separated workers, technicians, engineers and bosses. This form of classifying society was extensively studied by Hoggart (1973) in his tome on worker culture in an English borough. The division highlights and acknowledges the experience of exclusion and self-exclusion of workers in relation to the dominant groups or those in the service of domination. This is the perspective of class opposition and conscience of exploitation that, if on the one hand it indicates experiences of segregation, on the other, it reaffirms the will of capital to maintain workers at a distance, under hierarchization and inside their own universe. In this sense the phrase placed at the mine entrance is eloquent "Your family is only complete when you return home," as are the slogans that adorn all spaces in the mine, reminding them about seriousness, responsibility and workplace safety. The automatism created by "worktime-freetime," "mine-home," also contributed to the sentiment of exclusion in relation to other spheres of realization of human beings as citizens.

The strategy of maintaining the social division in the work structure is even clearer at present when, by demanding participation as an essential condition of productive restructuring, the company reduces it to the level of enhancing labor methods and processes. If everything related to personal needs and demands of workers was scarcely considered in the past, currently this type of problem has no place for expression in the formal mechanisms of social labor relations. Objectives, goals, intensified production, care of machinery and equipment completely occupy these spaces, times, minds and hearts of the workers. The Quality Control Circles (QCC) where workers gather and use their creativity and are even rewarded for it - are at no time willing to discuss personal issues, as they are 
exclusively focused on improving or innovating production processes. In turn, some forms of profit sharing and holding of stock were introduced to the collective of the workers. These are so strictly controlled by the bosses, however, that they do not allow any possibility for the workers to have any level of identity between them and management.

Another point of difference between "us" and "them" is the political field where Vale similarly interferes, albeit, indirectly. In the past, politics appeared as a supra-structural sphere of power similar to the idea of State to government. Submission to several management teams appointed by the federal government is part of the business culture, because Vale was state-run. This link was so strong that during the years of the military dictatorship in Brazil (1964-1979), the city of Itabira as a whole became an area of national security. Workers were closely watched at work, outside work and in their expressions of opinion. Yet, the idea of politics was always presented to the worker as a field of action of the "others," "them," as something inaccessible, as "workers are incapable," "don't know how to speak," "don't understand," "don't know how to make speeches." Contrarily, the sense of personal impotence for participation has always been associated, by workers, to the vision of "politics" as a space of corruption, underhandedness and disgust. In their view, politics as done by "them" (politicians) may even speak in name of the people, but rarely truly include the needs and interests of the "poor."

Speaking of how the company addresses the question nowadays, one of the workers in the equipment maintenance workshop carefully commented: "The Company is liberal. In general, bosses don't persecute anybody because of politics, but we feel that they prefer quiet workers to go home when they leave work."

Older employees revere President Getúlio Vargas' as the "second God who came to Earth," as the governor who "did something for workers," and that "gave us social legislation." Notwithstanding, the political meaning attributed to the government of Getúlio Vargas is that of one that resolved an important problem for the poor, that is, he offered them a gift: "He gave us workers Labor Legislation." Younger employees have a keener awareness of rights and for the most part critically follow the news on national and international politics. They know, more than ever, that actions and decisions outside the sphere of public and private authority affect their daily lives. Still, the wall separating "us" (workers) from "them" (politicians) continues in their minds. As mentioned previously, the level of participation generally includes only social solidarity movements, a type of inclusive insertion encouraged by the company.

It is important to stress a point that unites past and present in the scope of political behavior. Most of the miners have always voted and vote in opposition parties or more to the left: is this in disgust with those in power who are corrupt and "do nothing for them?" This type of behavior shows that politics is seen more for its effects than as a space of participation and

\footnotetext{
${ }^{6}$ Getúlio Vargas was born in 1882 and died in 1954. He was the 13th President of Brazil, leader of a civil revolution that ended a period of Brazilian history called República Velha. He governed the country for 15 uninterrupted years, from 1930 to 1945: from 1930 to 1934, as head of the "Provisional Government"; from 1934 to 1937, as President of the Republic via the Constitution, from 1937 to 1945, by means of a coup d'état. Getúlio was called by his supporters, especially the newborn working class, the "father to the poor," due to the fact that he enacted many of the social and labor laws in Brazil. His doctrine and political style became known as Getulism or Varguism.
} 
expression of citizenship. Some workers over the years were bold enough to run for mayor or city councilman and are considered courageous by their colleagues, though they are exceptions to the rule. Some assess and highlight, however, that many of their colleagues have entered politics, "interested in personal gain or to advance in life or to make a name for themselves," in a tone of disdain to those who left jobs at Vale, considered as honest and more gainful employment. Are they disillusioned with reality or is it reality itself that deludes them? (Marx, 1984)

Similar to politics, issues that mobilized the city until recently were considered the domain of "them," of "others." Categories that divided workers in relation to problems in Itabira, at first glance, may be understood by the fact that many are migrants. This argument, however, is not valid today. Over time, the majority settled in the city and many statements discriminate people from Itabira as workers who came some 20,30, 40 years ago to the city. In almost all of the interviews, until quite recently, the topic of the decadence of Itabira as a consequence of the progressive shutdown of the mine, pollution and environmental degradation caused by the pit excavations, or to think of alternatives for the economic and social future of the urban center, was seen as a subject that was the responsibility of the people of Itabira, from which the workers were excluded. "People from Itabira are lazy, they have no initiative," "they didn't know how to handle Vale," "people not united": these were and to a certain extent continue to be the most common judgments of workers and technicians regarding the inhabitants of the city. The issue, therefore, does not only refer to the status of migrant, rather, of feeling "outside," which can be understood, first because the terms people of Itabira, problems of Itabira are always used in the political sense, that is, in reference to those in power to govern. Second, this occurs as a long-term vision of class, encouraged by the ideology of the company. By delimiting the world of the worker as being a space of production, family, and at most, the neighborhood, Vale always implicitly reduced the meaning of citizenship to these spheres.

New workers evolved in relation to the feeling of belonging to Itabira society and social issues, through several movements of change. In the late 1980s, as part of Novo Sindicalismo (New Unionism) (Alves, 2000), there was more scope for debate and legitimacy of social discussions. This transformation can be seen in the Sindicato Metabase journals that began including topics referring to the city after the 1989 strike. The dissolution of incentive mechanisms such as segregated living spaces, educational system and healthcare contributed to this (Minayo, 2008), making workers perceive that they shared a common destiny with the local population. Yet, the period of insecurity and fear and the excessively technical and controlled discourse of the Toyota model, contaminated time and space of the miners with a type of collective individualism (Piore \& Sabel,1984, p.306) ${ }^{7}$ that compromised their social insertion. To me, use of this term refers to inciting concomitant processes of individual competition and group cooperation by the company within the labor process, which obviously transcends this scope. In a certain manner, the ethos of order, seriousness, quality and accountability for productivity replaced the national-developmental discourse

\footnotetext{
${ }^{7}$ Piore and Sabel speak of "collective individualism" to characterize the new type of ethos of groups of workers, characteristic of the information age, considering it the equivalent to what is called "competitive cooperation" that characterized artisan production in the 19th century. Here I reinterpret the terms used by the authors to speak of "small owner democracy" referring to what occurred in relations between small and large companies in what has been called the "Third Italy" since the 1960s.
} 
of national progress to which the worker had to contribute, yet it promotes the same result: total dedication to work, also consuming a large part of the time for recouping strength and social reproduction.

The view of the miners is that the Union occupies an ambiguous place: at times it is considered "us"; at times it occupies the place of "them." Until privatization, almost all workers were union members and the company itself encouraged this. The union, however, was not an entity for formation of class, as referring to it workers recognized it as "theirs," and very important, only for the medical, dental services and certain small social benefits it provided. Some felt the degree of legitimacy of the union went somewhat further: "The union is seen as a boss by the workers. Sometimes the worker there is unjustly considered guilty and sometimes he isn't strong enough to defend himself alone. But it is not for anything serious. It only resolves minor issues." Therefore, created by the company itself, (Minayo, 2008) the workers conceive the union as always having been an instrument more to the benefit of Vale. This is why it is more "theirs" than "ours." One older operator said: "The union fights, but it fights more for the Company. Every Company needs a union. It defends the company more than us."

The perception of the union as an "arm of the company," an expression used by several interviewees, explains a great deal of the mistrust felt by many miners. This belief hinders them from complaining about violations of their rights and from participating more actively in the formulation of demands. Only exceptionally has this traditional class entity appeared, in worker representation, as a collective space to be guided by right as a mouthpiece of the workers. The exceptions have always succumbed to a diffused yet widespread and strong fear of the sword of Damocles, exemplified by the singling out of leaders for dismissal, as shown in a broader study (Minayo, 2008).

Younger workers are no longer co-opted by the national-developmental ideology, as the management practice of the company leaves no doubt that their primary objective is profit. The current experience of exploitation of all, recent and long-timers, and the comparison of their lives and personal stories with the economic progress and expansion of Vale makes us doubt the belief, in the past almost unquestionable, that there was a convergence of interests between the company and its employees. The union, on the other hand, in a rare show of protagonist zeal in 1989, managed to demonstrate that it was committed to defending the interests of the workers, though the brevity of its appearance did not allow for a modification of the corporate culture. The union and the strategies of new unionism were soon swept aside by the premises of productive restructuring as relics of the Fordist model. The "us" and "ours" today, in relation to the union remain through the power of institutional reproduction, the rites of election and collective bargaining, possibly betting on future redefinitions.

Within the productive unit, supervisors, managers and directors are also targets of the division between "us" and "them": even today, in full exercise of mechanisms of greater horizontality and group and relational cooperation and participation in ongoing enhancement of the labor process, most of the factors that affect the lives of the workers occur outside their domain: "The thing I like least in the company is that I'm the last to know about things that affect me,. It's true that when I signed a contract I knew that they could do what they wanted, but I don't like it" said a facilities equipment maintenance mechanic. Actually, the distinction that exists within the labor process tends to identify and personalize the 
immediate "exploiter" as the real exploiter, and forego any analysis of the broader mechanisms that subordinate and expropriate them.

The self-exclusion by the workers in relation to a universe to which they feel foreign (politics, union, public administration, bosses and others) reflects not only the abandonment of a space for social protagonism, but also the active and positive value of repudiating the action of different social, institutional, political and union stakeholders, from which they exclude themselves. The statements of the workers did not spare criticism of "them" to which they are opposed. In the reports, politics appears not only as a space for corruption but also a refuge for "clever guys who want to earn more" or "exploiters of the people who live off of promises." Likewise, events narrated about internal corruption during the period that Vale was state-run are always attributed to the levels of 'management' and the 'big fish.' "If this Company wasn't solid, these management teams would have done it in." It is as if the division that they have imposed authorizes them to show a sort of indifference or disdain for values and codes imposed by the managing group.

\section{Some conclusions: Traits of identity and subjectivity}

The attempt at working on certain categories deemed most evident in the set of reports may leave a sense of false homogeneity in the worldview of the collective workers. Certainly there are some highlighted statements that reveal a more defined conscience of exploitation and place under scrutiny the monopolization by one group in society of the means of power, production and knowledge. These workers, however, are the exception. Miners who are more united and representative of the group studied, in the past and in the present, still see work as the center of their personal and social identity and the manner in which they can realize their participation as citizens. Therefore, although there is perennial resistance to exploitation, they value their job and believe that through it they will achieve their place in society. This miner is peaceful (which contradicts the violence of the productive process) law-abiding, who emphasizes family relations and has, in the family, the symbol of his peaceful and orderly character. He knows the "place" he is assigned in society and, assuming the division of class, excludes himself from participating in institutions and values that he deems foreign. Thus these workers are in themselves the expression and symbol of the mode of production to which they are submitted and the denial of that, in a divided society, which expropriates and excludes them. This conclusion seeks to extract all the external injunctions that make up their profile, to emphasize the sense of the collective that considers itself victorious because it is part of the founding group of the largest open pit iron mining company in the world.

The first workers were muscular, large-shouldered, firm-stepping with their heads bowed to the ground. Almost all of them black. They said little. Their dense words were full of wisdom that the fight for survival always results in. Their short phrases, penetrating because of the eloquent silence that subordination and resistance teach, are fragments of an epic history experienced in the harsh daily routine of the mines. Their eyes, sometimes lost in time, still sparkle with profound, proud light, transcending time and space, to glimpse the world of dreams, the drop of sweat carried in the millions of tons of ore wrenched by their arms, and carried over vast oceans.

Current workers differ from their pioneering colleagues in characteristics that show higher formal education and the labor process. The link to the past comes from the fact that almost 
all of them are the third generation of the first workers. More than mere coexistence in the same excavated pit - than the contemplation of the same deep pits left in remembrance of a Cauê that no longer exists - their identity passes from a generation of miners who were trained and disciplined by Vale and left in it their mark of pride and of their own transformation. We have approached some fundamental aspects. The fruit of labor unites their worlds, transforming them into universal artifices and interweaves their destinies with those of all other workers who, through them, shall also work with that iron. From their universe of mining, they join hands with this entire class of salaried laborers, slaves of time, their time past. Contradictorily, however, those of today feel privileged at the simple fact of being employed, of having a work card signed and for having certain rights that changes in the world of labor have not yet managed to achieve, namely the secrets of the wealthier capitalist. Now more than ever, the paradox that labor is the opposite of freedom and that no freedom is possible without it is realized in them, despite all academic discourse to the contrary.

Conscience? To the miners it is not only an extension of their antagonist vision of the company. They do not think or express themselves in abstract terms of economic and social relations. Their thoughts are concrete. The first, the pride of being the "lions of Vale" is clear. They were sure that, without them, the country's economy would not have been the same. Yet today, as yesterday, their solidarity with colleagues is apparent: solidarity that comes from the fact of being real people who work hard to survive and live from the fruit of their labor. Yesterday and today, the economic rationale of capital opposes the moral value of justice, of recognition and relations of loyalty. On the one hand, everyone knows they are being exploited and even consider it normal that the company should profit from their toil, while on the other, they always hoped to earn more, to grow and progress. They mistrust bosses just as they mistrust any change proposed to them, because they always imagine that it will only prejudice them, even when they adhere to it through a pure sense of convenience and opportunity.

In the initial period, workers withheld "pulo do gato" (tricks of the trade), in other words practical knowledge acquired through which they managed to enhance production, but that would benefit their supervisors more than themselves. Contrary to those who preached total expropriation of their knowledge, they discovered that their wisdom and art could be a mainstay of resistance to the tyranny of capital. The precious wealth of practical knowledge acquired in implementing the gears, adjusting them to the real operating conditions, in corrections required over time, led them to capture, in their daily routines, secrets and tricks of the tools of their trade. Their necessary and complementary knowledge, serving as a weapon of resistance, has now become a collection of participation. Participation led by and appreciated by the company, but of which they know the limits. They value it because it puts all other potential into action, before fragmented in the organization of labor. They mistrust it because it is all capitalized in favor of productivity: therefore the relation is horizontal; to personal demands and interests, everything must continue to be engulfed by or submitted to the rites of bureaucracy.

Today they have even relinquished this through exchanges, i.e. subtle forms of symbolic domination, and their knowledge is being incorporated into the equity of the company. Before, they prided themselves on the difficulty of their work, which was tough and dangerous, and compared themselves to the "bigshots" whose production, to them, was 
despicable and superfluous. Yet, if in the past they were timid before engineers who dominated the reading and appropriated their knowledge, today their practical knowledge is valued in participatory strategies and approximates them to the benefit of the competitiveness of the company. They measured their progress by job security, good salary and the upward social mobility of their children. Today, flexible logic motivates them to dedicate body and soul to enhance their value and compete: security is no more, salaries have decreased and the horizon for their children must go beyond the gates of the mines.

To them, the Company that previously was a "mother" who was almost never questioned continues to be the space from which they see the world and expand their horizons. They say, however, that it is "no longer a mother, nor even a stepmother," it is "just a company" and is no longer sacred, but that continues to warrant respect due to its size, dynamism, leadership and the fact that they helped build it by contributing the strength of their physical and mental, material and immaterial labor. They take from it the salary that sustains them. Evoking the company name gives them respect, honor, and credit in the city and in society and they can raise their families. Vale has always marked their present and future, imprinting on them a profound sense of dependence, and continues to write them into the culture of new customs in the labor process. To the younger workers, this feeling of belonging to the company and being up to date with productive flexibility translates the very essence of their condition as salaried workers.

The first Men of Iron cultivated, throughout their careers, a beautiful dream, albeit beautiful and fragile: "The Company is ours, the deposits are ours, the railroad is ours, and the port is ours. Everything is ours." This phrase of collective authorship, whose relevance corresponds to the sharp historical and ideological inflection experienced by the collective, brings to light the sweet illusion that motivated and encouraged them. It gave them courage to face the rain, wind, dust, weight of the tools, monotony of the work, the deafening roar of the machines and the arrogance and oppression of their superiors.

Today, as time goes by and the distance between them and the giant company grows, relations of the type of the "larger family" unravel in the impersonal measurements of productivity. Very little illusion remains: what is "ours" is not synonymous to what is "mine." They discover that is is all nothing more than a figure of speech and part of the disguise of exploitation. Many have been left by the wayside: they have lost their jobs and been replaced "without mercy or care" by the impersonal urgency of profit: they were old, rigid and their skills became disposable. Others were lowered in rank: they continue to serve the company, but with lower status, as underlings in outsourced companies. Many of those who experienced life in the state-run Vale lived through the transition and are coming to the end of their careers do not recognize themselves in the changes and only try to conform and to forget. They are aided by the voice of an abstract, superior and unarguable authority: productivity indicators, share price, company profits.

Thus, workers at Vale who called themselves the Men of Iron and who today are Iron but Flexible continue to be proud of their sweat and labor and transmit this to their families and children. The period of uncertainty, however, taught them an essential lesson. They understand perfectly that, under the present circumstances, they must remove the weight of the rigid metal from their shoulders and look at the world of labor with the same dexterity of spirit that the bosses have to resize and restructure it. They know they need to focus their 
minds on the strict demands of their daily work shifts. At the same time, they understand that they must make their minds fly abroad, far away, to other horizons and other dreams, projecting a future without a predetermined space. They know and repeatedly say that it is fundamental they invest in the construction of that which is flexible, cumulative and imponderable, which no company can ever capture: their professional growth, technological education, their interests and social life.

Therefore, personal goals of the great majority today take the path of personal enhancement and unequivocal investment in education of the highest quality possible for their children. Immersed in and coexisting with the current universe of uncertainties and opportunities, they manage to perceive that the point of support cannot only be in the world of work. The basics are their skills and individual performance and points of equilibrium, recognition in work, family life, and participation in the achievement of civic rights both locally and throughout the country.

With their gaze lost in space or feet planted firmly in reality from their experience, these men, both today and yesterday, speak of the country that grew rich on their sweat and toil; they speak of the Company as an unquestionable mother or as a successful company; they speak of successive management teams, which in their view are always imperfect. They feel themselves as citizens, but they do not forget their salaried condition, and conclude: "The rope always breaks prejudicing the weaker side ... that's how it's always been." Therefore, they know what they have to do, in addition to heavy investments in all their individual abilities, to reconstruct the class union that makes them strong and powerful, today more than ever made difficult by the ideology of productive restructuring that expects collective individualization from them.

\section{References}

Almeida, MET. 1999. Negociando a reforma: a privatização das empresas públicas no Brasil. Revista Dados, v.42, n. 3, 1999, p. 421-451, ISSN 0011-5258

Alveal, C. 1993. Os desbravadores: a Petrobrás e a construção do Brasil industrial, Editora Relume-Dumará, ISSN 978858542798-6, Rio de Janeiro

Alves, G. 1999. Trabalho e mundialização do capital: a nova degradação do trabalho na era da globalização, Editora Práxis, ISSN 978859972810-9, Londrina

Alves, G. 2000. O novo (e precário) mundo do trabalho: reestruturação produtiva e crise do sindicalismo, Editora Boitempo, ISSN 858593458-1, São Paulo

Alves, G. 2002. Trabalho e sindicalismo no Brasil: um balanço crítico da década neoliberal (1990-2000). Revista de Sociologia e Política, n.19, p. 71-94, 2002, ISSN 0104-4478

Alves, G. 2009. O espírito do toyotismo - reestruturação produtiva e captura da subjetividade do trabalho no capitalismo global. Confluências, v.10, p.97-120, ISSN 1645-9350

Antunes, R. 1999. Os sentidos do trabalho: ensaios sobre a afirmação e a negação do trabalho, Boitempo Editorial, ISBN 85-85934-43-3, São Paulo

Antunes, R. 2010. La dialéctica entre trabajo concreto y trabajo abstracto. Herramienta, v.1, p.39-46, ISSN1852-4710

Antunes, R. 2011. As formas diferenciadas da reestruturação produtiva e o mundo do trabalho no Brasil. Revista Latinoamerica de Estúdios del Trabajo, v.1, p. 35-49, ISSN 1856-8378 
Anuatti Neto, F.; Carvalho, A.G.; Barossi Filho, M. \& Macedo, R.B. 2005. Os Efeitos da Privatização sobre o Desempenho Econômico e Financeiro das Empresas Privatizadas. Revista Brasileira de Economia, v. 59, p. 151-175, ISSN 0034-7140

Araújo, A.M.C. 2001. Globalização e trabalho: uma revisão da literatura. Revista Brasileira de Informação Bibliográfica em Ciências Sociais, n. 52, p. 5-44, ISSN15168085

Araújo, A.M.C; Justo, M.C. ; Mello, C. R.D. 2001. Reestruturação produtiva e negociação coletiva nos anos 90. Revista Brasileira de Ciências Sociais, v.16, n. 45, p. 85-112, ISSN0102-6909

Bell, D. 1973. The coming of post-industrial society, Basic Books, ISBN 0-465-01281-7, New York

Bettelheim, C. 1970. La planification soviétique. Paris: Éditions Rivière. ISSN 12172763 (10a. edition)

Blauner, R. 1964. Alienation and Freedom: the factory worker and his industry, The University Press, ISBN 0226058115, Chicago.

Blin, J.F. 1997. Répresentations, pratiques et identités profissionales. L'Harmattan, ISBN 2738450407, Paris.

Boito Junior, A. 1999. Política neoliberal e sindicalismo no Brasil, Editora Xamã, ISSN 8585833513 , São Paulo.

Bourdieu, P. 1963. Travail et Travailleur en Algérie: étude sociologique. Mouton et Co. ISSN 2707301574, Paris

Bourdieu, P. 1980. Le sens pratique. Éditions Minuit, ISBN 2707302988, Paris.

Carleal, L.; Valle, R. (Org(s).). 1997. Reestruturação Produtiva e Mercado de Trabalho no Brasil, Editora Hucitec-Abet, ISSN 8527103966, São Paulo

Cardoso, A.M. 1999. Sindicato, trabalhadores e a coqueluche neoliberal: a era Vargas acabou?, Editora FGV, ISSN. 852250265x, Rio de Janeiro

Cardoso, A.M. 2001. A filiação sindical no Brasil. Revista Dados, v. 44, n. 1, p. 15-52, ISSN 0011-5258

Castells, M. 1996. The rise of the network society. Blackwell Editors, ISSN 1557866163, Oxford

Castells, R. 1998. As metamorfoses da questão social: uma crônica do salário, Editora Vozes, ISSN 8532619541, Petrópolis.

Chesnais, F. 1996. A mundialização do capital. Xamã, ISSN 8585833149, São Paulo

Companhia Vale do Rio Doce. (2001). Institucional. Rio de Janeiro. 02/10/2011, Disponível em: http://www.vale.com/pt-br/Paginas/default.aspx.

Diniz, E. 1978. Empresário, Estado e Capitalismo no Brasil: 1930-1945. Rio de Janeiro: Editora Paz e Terra. ISBN 0000142930

Dutra, P.P.A. 1991. Controle de empresas estatais: uma proposta de mudança, Editora Saraiva, ISSN 8502009141, São Paulo

Engels, F. 1990. Anti-Düring. Editora paz e Terra, 1990 (3ª .ed). ISBN 8521904800-São Paulo

Ford, H. \& Crowther, S. 2005. My life and work. Dodo Press, ISBN 9781406500189. New York

Gomes, A.M.C. 1979. Burguesia e Trabalho: Política e Legislação Social no Brasil (1917-1937), Editora Campus, ISSN 8570010338, Rio de Janeiro

Gomes, A.M.C. 1988. A Invenção do Trabalhismo, Editora FGV, ISBN 852250508-X, São Paulo

Gramsci, A. 1971. Americanism and fordism, In: Slections from the prision notebooks of Antonio Gramsci, Hoare, Q.; Nowell Smith (Org(s).), p. 277-318, Lawrence and Wishart Editors, ISSN 0-85315-280-2, Londres 
Harvey, D. 2001. A condição pós-moderna, 10ª ed., Editora Loyola, ISSN85-209-0411-4, São Paulo

Hoggart, R. 1973. Utilizações da Cultura, v. 1, Editorial Presença, ISBN 9722311670, Lisboa

Hoggart, R. 1973. Utilizações da Cultura, v. 2, Editorial Presença, ISBN 9722311700, Lisboa

Kunar, K. 1995. Da Sociedade Pós-Industrial à Pós-Moderna, Editora Jorge. Zahar, ISSN 8571103941, Rio de Janeiro

Leite Lopes, J.S. 1976. Vapor do Diabo. Paz e Terra, ISSN 2000000756325, Rio de Janeiro

Leite Lopes, J.S. 2009. História e Transformações do Sindicalismo Brasileiro. Revista Theomai (Online), v. 19, p. 1-2, ISSN1666-2830

Lojkine, J. 1981. O Estado Capitalista e a Questão Urbana: novas direções, Martins Fontes, ISBN 8533605846,

Marx, K.; Engels, F. 1984. Ideologia Alemã, Editora Hucitec, ISSN 85.271.0005-3, São Paulo

Marx, K. 1978. Capítulo inédito de O Capital (livro 1), cap. VI, Donnelley Cochrane/Editora Brasil, ISBN 85-351-0831, São Paulo.

Mattoso, J. E. 1995. A desordem do trabalho, Editora Scritta, ISBN 85-85328-96-7, São Paulo

Minayo, M.C.S. 2008. De Ferro e Flexíveis, Editora Garamond, ISBN 85-7617-38-8, São Paulo

Minayo, M.C.S. O desafio do conhecimento. Pesquisa Qualitativa em Saúde. Editora Hucitec, ISBN 8527101815, São Paulo.

Murard, L.; Zylberma, P. 1980. Le Petit Travailleur Infatigable, Editions Maspero, ISBN 2.86222.024.8, Paris

Ohmae, K. 1990. The bordeless world: power and strategy in the interlinked economy, Harper Collins Business. ISBN 978088730967, Londres

Pinheiro, A.C. , Giambiagi, F. 1992. As empresas estatais e o programa do governo Collor. Pesquisa e Planejamento Econômico, v.22, n.2, p. 241-28, ISSN 0100-0551

Piore, M. ; Sabel, C.F. 1984. The second industrial divide: possibilities for prosperity, Basic Books, ISBN 0465075614 , New York

Pritchard, E.E. 1978. Os Nuer,Editora Perspectiva, ISBN 9788527301923, São Paulo

Ramalho, J. R. 2010. Flexibilidade e crise do emprego industrial: sindicatos, regiões e novas ações empresariais. Sociologias, v. 12, p. 252-284, ISSN 1517-4522, Porto Alegre.

Rodrigues, L.M. 1999. Destino do Sindicalismo, Editora Edusp, ISBN 9788531405174, São Paulo.

Sennett, R. 1998. The corrosion of character: the personal consequences of work in the new capitalism. Norton \& Company, ISBN 100393319873, New York.

Sorj, B. 2000. Sociologia do Trabalho: mutações, encontros e desencontros. Revista Brasileira de Ciências Sociais, v. 15, n. 43, p. 25-34, ISSN 0102-6909

Tauille, J.R. 2001. Para reconstruir o Brasil Contemporâneo: trabalho, tecnologia e acumulação. São Paulo: Editora Contraponto. ISBN 8585910402

Thompson, E.P. 1968. The Making of the English Working Class, Penguin Books. ISBN 0394703227, England

Toffler, A. 197o. Future shock, Random House, ISBN 0394425863, New York

Turner, A.; Lawrence, P. R. 1965. Industrial Jobs and the Worker: An Investigation of Response to Task Attributes, Harvard University, ISBN 0875840426, Boston

Verret, M. \& Creusen, J. 1996. Culture Ouvière. Éditeur: L'Harmattan, ISBN: 2-7384-4536-5, Paris.

Waddington, J. (Org.). 1999. Globalization and patterns of labour resistence, Mansell, ISBN 0720123690, Londres 
Weber, M. 1969. La Ética Protestante y el Espiritu del Capitalismo, Península, ISBN 9789681669089, Barcelona 


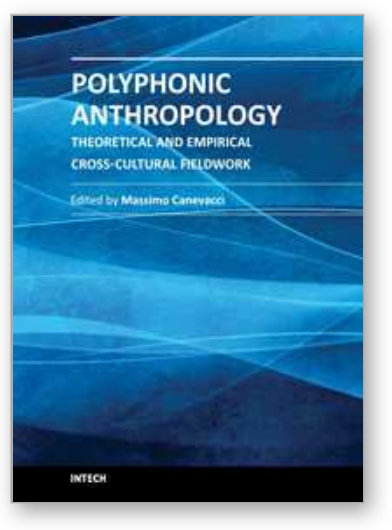

\author{
Polyphonic Anthropology - Theoretical and Empirical Cross- \\ Cultural Fieldwork \\ Edited by Prof. Massimo Canevacci
}

ISBN 978-953-51-0418-6

Hard cover, 242 pages

Publisher InTech

Published online 23, March, 2012

Published in print edition March, 2012

This book connects anthropology and polyphony: a composition that multiplies the researcher's glance, the style of representation, the narrative presence of subjectivities. Polyphonic anthropology is presenting a complex of bio-physical and psycho-cultural case studies. Digital culture and communication has been transforming traditional way of life, styles of writing, forms of knowledge, the way of working and connecting. Ubiquities, identities, syncretisms are key-words if a researcher wish to interpret and transform a cultural contexts. It is urgent favoring trans-disciplinarity for students, scholars, researchers, professors; any reader of this polyphonic book has to cross philosophy, anatomy, psychology, psychoanalysis, sociology, architecture, archeology, biology. I believe in an anthropological mutation inside any discipline. And I hope this book may face such a challenge.

\title{
How to reference
}

In order to correctly reference this scholarly work, feel free to copy and paste the following:

Maria Cecilia Minayo (2012). Imprints of the Entrepreneurial State and Privatization on Worker Subjectivity - A Study of Iron Ore Mine Workers in Itabira - Minas Gerais, Brazil, Polyphonic Anthropology - Theoretical and Empirical Cross-Cultural Fieldwork, Prof. Massimo Canevacci (Ed.), ISBN: 978-953-51-0418-6, InTech, Available from: http://www.intechopen.com/books/polyphonic-anthropology-theoretical-and-empirical-crosscultural-fieldwork/imprints-of-the-entrepreneurial-state-and-privatization-on-worker-subjectivity-

\section{INTECH}

open science | open minds

\author{
InTech Europe \\ University Campus STeP Ri \\ Slavka Krautzeka 83/A \\ 51000 Rijeka, Croatia \\ Phone: +385 (51) 770447 \\ Fax: +385 (51) 686166 \\ www.intechopen.com
}

\author{
InTech China \\ Unit 405, Office Block, Hotel Equatorial Shanghai \\ No.65, Yan An Road (West), Shanghai, 200040, China \\ 中国上海市延安西路65号上海国际贵都大饭店办公楼 405 单元 \\ Phone: +86-21-62489820 \\ Fax: $+86-21-62489821$
}


(C) 2012 The Author(s). Licensee IntechOpen. This is an open access article distributed under the terms of the Creative Commons Attribution 3.0 License, which permits unrestricted use, distribution, and reproduction in any medium, provided the original work is properly cited. 